\title{
Population structure and diversity of avian isolates of Pasteurella multocida from Australia
}

\author{
Patrick J. Blackall, ${ }^{1}$ Narelle Fegan, ${ }^{1}+$ Gerard T. I. Chew ${ }^{2}$ \\ and David J. Hampson ${ }^{2}$ \\ Author for correspondence: Pat Blackall. Tel: +61733629498 . Fax: +61733629429. \\ e-mail: blackap@dpi.qld.gov.au
}

1 Animal Research Institute, Yeerongpilly, Queensland 4105, Australia

2 Division of Veterinary and Biomedical Sciences, Murdoch University, Murdoch, Western Australia 6150, Australia

\begin{abstract}
A total of $\mathbf{1 1 0}$ isolates of Pasteurella multocida from Australian poultry and reference strains for the 16 somatic serovars plus the three subspecies (gallicida, multocida, septica) were analysed to examine their population structure and diversity. The 81 field isolates examined by multilocus enzyme electrophoresis (MLEE) were diverse, being divided into 56 electrophoretic types (ETs), with the 19 reference strains in another 15 ETs. The population was clonal and somatic serotyping was not particularly useful in establishing relationships between isolates. The 71 ETs formed three distinct subclusters ( $A$, $B$ and $C$ ) at a genetic distance of 0.36 . Biovars tended to be associated with these subclusters: A with biovars 1, 3, 4, 5 and 8 and $B$ with biovars 2, 6, 7, 9 and 10. Ribotyping, performed on all 110 isolates using Hpall, recognized 21 ribotypes forming nine clusters (R1-R9). The isolates in ribotype cluster R1 were almost identical to those in MLEE cluster $B$. Using both MLEE and ribotyping, the 19 non-Australian reference strains were found to be distributed over the full diversity of the Australian isolates of $P$. multocida. This study has shown that a range of $P$. multocida clones are associated with fowl cholera in Australia and that many of the Australian isolates are similar to non-Australian reference strains. Both the MLEE results and the ribotyping data identified a previously unrecognized subset of $P$. multocida strains.
\end{abstract}

Keywords: Pasteurella multocida, multilocus enzyme electrophoresis, ribotype, genetic diversity

\section{INTRODUCTION}

Pasteurella multocida is the causative agent of fowl cholera, a common and widely distributed disease of poultry that is of major economic importance (Rimler \& Glisson, 1997). There is considerable evidence that avian isolates of $P$. multocida are diverse. Using DNA-DNA hybridization, Mutters et al. (1985) recognized three subspecies within P. multocida (multocida, septica and gallicida). The distribution of these subspecies in various types of birds is known to differ, e.g. it has been reported that subsp. gallicida is more common in waterfowl and associated wild birds in California than it is in domestic turkeys (Hirsh et al., 1990). There is also considerable

†Present address: CSIRO, Division of Food Science \& Technology, PO Box 3312, Tingalpa DC 4173, Australia.

Abbreviations: ET, electrophoretic type; MLEE, multilocus enzyme electrophoresis; ODC, ornithine decarboxylase. serological diversity with most of the 16 Heddleston somatic serovars having been isolated from birds (Rhoades \& Rimler, 1987). The molecular-based techniques of restriction endonuclease analysis and ribotyping have been used extensively to demonstrate considerable diversity in avian isolates of $P$. multocida (Kim \& Nagaraja, 1990; Snipes et al., 1990; Carpenter et al., 1991; Christiansen et al., 1992a, b; Wilson et al., 1993, 1995; Blackall et al., 1995).

While this evidence of diversity is well known, there has been no attempt to assemble an overview of the overall population structure of avian $P$. multocida isolates in relation to this diversity. Studies on population structure in other bacterial pathogens have provided considerable insights (Musser, 1996). Such studies show that particular subgroups or clones of a species are associated with virulence, e.g. in Streptococcus agalactiae (Quentin et al., 1995) and Enterococcus faecalis (Tomayko \& Murray, 1995). Typically, population structure studies 
Table 1. Properties of isolates used in this study

\begin{tabular}{|c|c|c|c|c|c|c|}
\hline Study code ${ }^{*}$ & $\begin{array}{l}\text { Somatic } \\
\text { serovart }\end{array}$ & Biovar $\ddagger$ & Ribotype & $\begin{array}{l}\text { Ribotype } \\
\text { cluster }\end{array}$ & ET & $\begin{array}{l}\text { MLEE } \\
\text { cluster }\end{array}$ \\
\hline PM63, 66 & 3 & 3 & 2 & R5 & $\mathrm{A} 1$ & A \\
\hline PM68 & $4 \times 12$ & 3 & 2 & $\mathrm{R} 5$ & $\mathrm{~A} 1$ & $\mathrm{~A}$ \\
\hline PM70 & 3 & 3 & 2 & R5 & $\mathrm{A} 1$ & $\mathrm{~A}$ \\
\hline PM73 & 4 & 3 & 2 & R5 & $\mathrm{A} 2$ & A \\
\hline PM46 & 6 & 1 & 7 & $\mathrm{R} 4$ & $\mathrm{~A} 3$ & A \\
\hline PM83 & Non-typeable & 1 & 12 & R7 & A4 & $\mathrm{A}$ \\
\hline PM71 & 4 & 1 & 20 & R5 & A5 & $\mathrm{A}$ \\
\hline PM37 & 3 & 1 & 12 & R7 & A6 & $\mathrm{A}$ \\
\hline PM35, 40, 85, 86 & 3 & 3 & 5 & R3 & A7 & A \\
\hline PM31 & 3 & 3 & 5 & R3 & A8 & A \\
\hline PM49 & $1 \times 15$ & 1 & 14 & R6 & A9 & A \\
\hline PM88 & Non-typeable & 1 & 3 & $\mathrm{R} 6$ & $\mathrm{~A} 10$ & $\mathrm{~A}$ \\
\hline PM45 & $3 \times 4$ & 3 & 5 & R3 & A11 & A \\
\hline PM87 & 3 & 3 & 5 & R3 & A11 & A \\
\hline PM120, 121 & 12 & 3 & 11 & R5 & $\mathrm{A} 12$ & $\mathrm{~A}$ \\
\hline PM51 & $4 \times 12$ & 3 & 11 & R5 & $\mathrm{A} 13$ & $\mathrm{~A}$ \\
\hline PM67 & $3 \times 12$ & 4 & 13 & R7 & A14 & $\mathrm{A}$ \\
\hline PM76 & Non-typeable & 5 & 9 & $\mathrm{R} 8$ & A15 & A \\
\hline PM64 & 3 & 5 & 9 & $\mathrm{R} 8$ & A16 & A \\
\hline PM65 & 4 & 5 & 9 & $\mathrm{R} 8$ & A16 & $\mathrm{A}$ \\
\hline PM96 & 3 & 4 & 13 & R7 & A17 & $\mathrm{A}$ \\
\hline PM48 & $3 \times 4$ & 3 & 2 & $\mathrm{R} 5$ & A18 & A \\
\hline PM27 & 3 & 3 & 2 & R5 & A19 & $\mathrm{A}$ \\
\hline PM52 & $3 \times 4 \times 12$ & 3 & 2 & R5 & A20 & $\mathrm{A}$ \\
\hline PM94 & Non-typeable & 3 & 2 & R5 & A 20 & $\mathrm{~A}$ \\
\hline PM77 & 3 & 3 & 10 & $\mathrm{R} 2$ & A21 & $\mathrm{A}$ \\
\hline PM18 & 3 & 3 & 10 & $\mathrm{R} 2$ & A22 & $\mathrm{A}$ \\
\hline PM32 & 3 & 3 & 10 & $\mathrm{R} 2$ & $\mathrm{~A} 23$ & $\mathrm{~A}$ \\
\hline PM78 & 3 & 3 & 5 & R3 & A24 & $\mathrm{A}$ \\
\hline PM136 & 3 & 3 & 5 & R3 & $\mathrm{A} 25$ & $\mathrm{~A}$ \\
\hline PM80 & $3 \times 4 \times 12$ & 3 & 5 & R3 & A26 & A \\
\hline PM134 & $4 \times 7$ & 1 & 3 & R3 & A 27 & $\mathrm{~A}$ \\
\hline PM95 & 3 & 3 & 5 & R3 & A28 & $\mathrm{A}$ \\
\hline PM75 & $3 \times 4 \times 12 \times 14$ & 3 & 5 & R3 & A29 & $\mathrm{A}$ \\
\hline PM74 & $3 \times 4 \times 14$ & 3 & 5 & R3 & $\mathrm{A} 30$ & $\mathrm{~A}$ \\
\hline PM19 & 3 & 3 & 5 & R3 & A31 & $\mathrm{A}$ \\
\hline PM69 & Non-typeable & 3 & 5 & R3 & A32 & $\mathrm{A}$ \\
\hline PM132 & 4 & 3 & 2 & R5 & A33 & $\mathrm{A}$ \\
\hline PM97 & Non-typeable & 3 & 11 & R5 & A34 & $\mathrm{A}$ \\
\hline PM133 & 4 & 3 & 1 & $\mathrm{R} 1$ & A35 & $\mathrm{A}$ \\
\hline PM137 & $4 \times 7$ & 3 & 1 & $\mathrm{R} 1$ & A36 & A \\
\hline PM84 & Non-typeable & 1 & 12 & R7 & A37 & $\mathrm{A}$ \\
\hline PM2, 10 & 4 & 3 & 7 & $\mathrm{R} 4$ & A38 & A \\
\hline PM3 & $4 \times 10 \times 15$ & 3 & 7 & $\mathrm{R} 4$ & A38 & $\mathrm{A}$ \\
\hline PM4 & 3 & 3 & 7 & $\mathrm{R} 4$ & A38 & $\mathrm{A}$ \\
\hline PM5, $6,7,9,11$ & Non-typeable & 3 & 7 & $\mathrm{R} 4$ & A38 & $\mathrm{A}$ \\
\hline PM8 & 10 & 3 & 7 & R4 & A38 & $\mathrm{A}$ \\
\hline PM15 & $11 \times 12$ & 3 & 7 & R4 & A38 & $\mathrm{A}$ \\
\hline PM16 & $11 \times 12 \times 15$ & 3 & 7 & R4 & A38 & $\mathrm{A}$ \\
\hline PM79 & 1 & 8 & 15 & $\mathrm{R} 2$ & A39 & A \\
\hline PM130 & 1 & 8 & 15 & $\mathrm{R} 2$ & $\mathrm{~A} 40$ & $\mathrm{~A}$ \\
\hline PM92 & 3 & 3 & 5 & $\mathrm{R} 3$ & A41 & $\mathrm{A}$ \\
\hline PM1 & $3 \times 4$ & 2 & 6 & $\mathrm{R} 1$ & $\mathrm{~A} 42$ & B \\
\hline PM12 & $3 \times 4$ & 2 & 6 & $\mathrm{R} 1$ & A43 & B \\
\hline PM13, 14 & 3 & 2 & 6 & $\mathrm{R} 1$ & A43 & B \\
\hline PM91 & 3 & 2 & 6 & $\mathrm{R} 1$ & A44 & $\mathrm{B}$ \\
\hline PM17 & 3 & 2 & 7 & $\mathrm{R} 4$ & $\mathrm{~A} 45$ & $\mathrm{~B}$ \\
\hline PM141 & 3 & 1 & 4 & R1 & $\mathrm{A} 46$ & $\mathrm{~B}$ \\
\hline PM135 & 13 & 10 & 4 & $\mathrm{R} 1$ & A47 & B \\
\hline
\end{tabular}


Table 1. (cont.)

\begin{tabular}{|c|c|c|c|c|c|c|}
\hline Study code* & $\begin{array}{l}\text { Somatic } \\
\text { serovar }\end{array}$ & Biovar $\neq$ & Ribotype & $\begin{array}{l}\text { Ribotype } \\
\text { cluster }\end{array}$ & ET & $\begin{array}{l}\text { MLEE } \\
\text { cluster }\end{array}$ \\
\hline PM140 & $13 \times 14 \times 15$ & 7 & 4 & $\mathrm{R} 1$ & A48 & B \\
\hline PM44 & 1 & 9 & 4 & $\mathrm{R} 1$ & A49 & B \\
\hline PM36 & 14 & 9 & 4 & $\mathrm{R} 1$ & A50 & B \\
\hline PM90, 93 & Non-typeable & 9 & 4 & $\mathrm{R} 1$ & A50 & B \\
\hline PM72 & $3 \times 14$ & 6 & 4 & $\mathrm{R} 1$ & A51 & B \\
\hline PM81 & Non-typeable & 6 & 4 & $\mathrm{R} 1$ & A52 & $\mathrm{B}$ \\
\hline PM139 & $1 \times 15$ & 2 & 4 & $\mathrm{R} 1$ & A53 & B \\
\hline PM138 & $1 \times 15$ & 2 & 4 & $\mathrm{R} 1$ & A54 & B \\
\hline PM131 & 1 & 2 & 4 & $\mathrm{R} 1$ & A55 & B \\
\hline PM82 & $1 \times 15$ & 8 & 15 & $\mathrm{R} 2$ & A56 & $\mathrm{C}$ \\
\hline ATS16 & 16 & 3 & 18 & R9 & $\mathrm{R} 1$ & $\mathrm{~A}$ \\
\hline ATS15 & 15 & 2 & 19 & R3 & $\mathrm{R} 2$ & A \\
\hline ATS10 & 10 & 3 & 11 & $\mathrm{R} 5$ & R3 & A \\
\hline ATS4 & 4 & 3 & 7 & $\mathrm{R} 4$ & R4 & A \\
\hline ATS13 & 13 & 1 & 16 & R7 & R5 & A \\
\hline ATS14 & 14 & 11 & 16 & R7 & R5 & A \\
\hline ATS1 & 1 & 1 & 16 & $\mathrm{R} 7$ & R6 & A \\
\hline ATS5 & 5 & 3 & 18 & R9 & R7 & A \\
\hline ATS3 & 3 & 3 & 5 & R3 & $\mathrm{R} 8$ & A \\
\hline ATS6 & 6 & 1 & 21 & R4 & R9 & $\mathrm{A}$ \\
\hline ATS11 & 11 & 1 & 11 & R5 & $\mathrm{R} 10$ & A \\
\hline ATS12 & 12 & 3 & 19 & R3 & $\mathrm{R} 10$ & $\mathrm{~A}$ \\
\hline ATS2 & 2 & 3 & 8 & R3 & $\mathrm{R} 11$ & A \\
\hline $\begin{array}{l}\text { P. multocida } \\
\text { subsp. multocida }\end{array}$ & $\mathrm{NK}$ & 11 & 17 & R6 & $\mathrm{R} 12$ & $\mathrm{~A}$ \\
\hline $\begin{array}{l}\text { P. multocida } \\
\text { subsp. gallicida }\end{array}$ & NK & 2 & 13 & R7 & $\mathrm{R} 13$ & A \\
\hline ATS7 & 7 & 7 & 4 & $\mathrm{R} 1$ & R14 & B \\
\hline ATS8 & 8 & 7 & 4 & $\mathrm{R} 1$ & $\mathrm{R} 14$ & B \\
\hline ATS9 & 9 & 2 & 4 & $\mathrm{R} 1$ & R14 & B \\
\hline $\begin{array}{l}P . \text { multocida } \\
\text { subsp. septica }\end{array}$ & NK & 7 & 6 & $\mathrm{R} 1$ & $\mathrm{R} 15$ & $\mathrm{~B}$ \\
\hline $\begin{array}{l}\text { PM204, 205, } \\
206,207,208, \\
209,210,211, \\
212,213,214\end{array}$ & NK & 3 & 2 & $\mathrm{R} 5$ & NK & NK \\
\hline PM89 & Non-typeable & 9 & 4 & $\mathrm{R} 1$ & NK & NK \\
\hline PM119 & 3 & 3 & 5 & R3 & NK & NK \\
\hline PM147 & 7 & 3 & 5 & R3 & NK & NK \\
\hline PM149, 150 & 3 & 3 & 5 & R3 & $\mathrm{NK}$ & NK \\
\hline PM224 & NK & 3 & 5 & R3 & NK & NK \\
\hline PM225 & NK & 3 & 5 & $\mathrm{R} 3$ & NK & NK \\
\hline PM226 & NK & 3 & 5 & R3 & NK & NK \\
\hline PM142 & 3 & 2 & 6 & $\mathrm{R} 1$ & NK & NK \\
\hline PM146 & 7 & 5 & 6 & $\mathrm{R} 1$ & NK & NK \\
\hline PM148 & $1 \times 10 \times 12$ & 5 & 6 & $\mathrm{R} 1$ & NK & NK \\
\hline PM145 & NK & 1 & 7 & $\mathrm{R} 4$ & NK & NK \\
\hline PM144 & NK & 2 & 8 & R3 & NK & NK \\
\hline PM221, 222, 223 & NK & 3 & 10 & $\mathrm{R} 2$ & NK & NK \\
\hline PM143 & NK & 8 & 15 & $\mathrm{R} 2$ & NK & NK \\
\hline PM151 & $1 \times 15$ & 8 & 15 & $\mathrm{R} 2$ & NK & NK \\
\hline
\end{tabular}

*Australian field isolates were given PM codes. The somatic serovar reference strains were given ATS codes where ATS1 means the reference strain for somatic serovar 1.

†Cross reactions are indicated by $\times$, e.g. $3 \times 4$ indicates cross-reacting with serovars 3 and 4 . NK, not known.

$\ddagger$ Biovars as defined by Fegan et al. (1995). 
are based on the technique known as multilocus enzyme electrophoresis (MLEE) (Musser, 1996). As well as insights into pathogenicity, MLEE studies have also provided considerable new knowledge on the epidemiology of disease outbreaks associated with a range of bacteria, e.g. Mycobacterium avium (Feizabadi et al., 1996) and Neisseria meningitidis (Weis \& Lind, 1996).

In this study, we have described a polyphasic approach that attempts to generate an overall view of the population structure of a collection of avian P. multocida isolates. We analysed an extensive collection of Australian avian isolates plus type strains for the three subspecies and 16 somatic serovars using a range of techniques-extended phenotypic characterization, serological characterization, MLEE and ribotyping.

\section{METHODS}

Bacteria. A total of 129 isolates of $P$. multocida were used in this study. They consisted of 110 isolates from Australian poultry, all previously characterized phenotypically (Fegan et al., 1995) and 19 reference strains. The Australian field isolates have been assigned to one of 10 biovars as well as one of the three subspecies (multocida, septica and gallicida) on the basis of ornithine decarboxylase (ODC) activity and ability to ferment six carbohydrates (arabinose, dulcitol, maltose, sorbitol, trehalose and xylose) (Fegan et al., 1995). The isolates were serotyped by the Heddleston somatic serotyping scheme (Heddleston et al., 1972). The Australian field isolates were obtained from chickens (44 isolates), turkeys ( 36 isolates) and a duck (one isolate), all having been diagnosed as suffering from fowl cholera. The isolates were collected over the period 1966-1994. The 19 reference strains consisted of the 16 reference strains for the Heddleston somatic serotyping scheme and the reference strains for the three subspecies of $P$. multocida - NCTC 10204 ( $P$. multocida subsp. gallicida), NCTC 10322 (P. multocida subsp. multocida) and CIP A125 ( $P$. multocida subsp. septica). The attributes of the $P$. multocida isolates and reference strains are listed in Table 1. All 19 reference strains were used in the restriction endonuclease analysis, ribotyping and MLEE work. While all 110 field isolates were used in the ribotyping study, only 81 of the field isolates were analysed in the MLEE study.

Bacterial growth, enzyme preparation and DNA extraction. Isolates were grown overnight at $37^{\circ} \mathrm{C}$ in Brain Heart Infusion broth (BBL). Following this incubation, samples were plated onto blood agar to check for contamination. The bacteria were harvested by centrifugation $\left(15000 \mathrm{~g}, 20 \mathrm{~min}, 4^{\circ} \mathrm{C}\right)$. For MLEE, the bacterial pellet was resuspended in PBS ( $\mathrm{pH} 7 \cdot 2$ ), centrifuged again and the resultant pellet resuspended in $2 \mathrm{ml}$ sonication buffer (10 mM Tris/ $\mathrm{HCl}, 1 \mathrm{mM}$ EDTA, $0.5 \mathrm{mM}$ $\mathrm{NADP}, \mathrm{pH} 6 \cdot 8$ ). The bacteria were lysed by three $1 \mathrm{~min}$ cycles of sonication on ice with $30 \mathrm{~s}$ cooling periods. The cell debris was removed by centrifugation $\left(25000 \mathrm{~g}, 20 \mathrm{~min}, 4^{\circ} \mathrm{C}\right)$ and the supernatant was stored at $-70^{\circ} \mathrm{C}$ until used. For the restriction endonuclease analysis and ribotyping study, the bacterial pellet was washed in $5 \mathrm{ml} \mathrm{SE}$ buffer $(150 \mathrm{mM} \mathrm{NaCl}$, $100 \mathrm{mM}$ EDTA, pH 8) and duplicate cell pellets were retained and held at $-20^{\circ} \mathrm{C}$ until required for extraction. DNA extraction was performed by a standard methodology as described previously (Blackall et al., 1995). DNA concentration and purity were determined spectrophotometrically.

MLEE. The bacterial lysates were electrophoresed in $14 \%$ horizontal starch gels (Selander et al., 1986). The following 18 enzymes displayed strong activity and good resolution, enabling mobility comparisons to be made between isolates: adenylate kinase (ADK), arginine phosphokinase (APK), catalase (CAT), esterase (EST), fumerase (FUM), glucose-6phosphate dehydrogenase (G6PD), NAD-dependent glyceraldehyde-3-phosphate dehydrogenase (GP), glutamate-oxaloacetate transaminase (GOT), NADP-dependent glutamate dehydrogenase (GDH), hexokinase (HEX), Ł-leucyl-L-tyrosine peptidase (LT), malate dehydrogenase (MDH), malic enzyme (ME), mannose-6-phosphate isomerase (MPI), nucleoside phosphorylase (NP), phosphoglucomutase (PGM), phosphoglucose isomerase (PGI) and 6-phosphogluconate dehydrogenase (6PGD).

Analysis of MLEE data. The banding patterns were consistent with a single locus for each enzyme and mobility variants were interpreted as the products of different alleles at the corresponding locus. Groups of one or more isolates with the same alleles at all loci were referred to as being an electrophoretic type (ET). Genetic diversity $(h)$ at each enzyme locus was calculated as $h=\left(1-\mathrm{SP}_{\mathrm{i}}^{2}\right)[n /(n-1)]$, where $P_{\mathrm{i}}$ is the frequency of the $i$ th allele and $n$ is the number of ETs or isolates in the sample (Nei, 1978). Total genetic diversity $(H)$ was calculated as the mean of $b$ over all loci. Diversity among isolates of serovar 3 was also calculated. Genetic distances between ETs were calculated as the proportion of fixed loci at which dissimilar alleles occurred and the unweighted pairgroup method of arithmetic means clustering fusion strategy was used to create a phenogram to show the relationships between isolates (Sneath \& Sokal, 1973).

The matrix of coefficients used for allelic mismatches between pairs of isolates was also used for calculating the index of association $\left(I_{\mathrm{A}}\right)$. This index, which describes multilocus linkage disequilibrium in bacterial populations (Maynard Smith et al., 1993), is significantly different from zero for a clonal population. $I_{\mathrm{A}}$ was calculated for the $56 \mathrm{ET}$ s containing Australian isolates.

Ribotyping. Total DNA (5 mg) was digested with HpaII (Boehringer Mannheim) in Tris/acetate buffer (O'Farrell et al., 1980) using 6.25 $\mathrm{U}$ enzyme per $50 \mu \mathrm{l}$ reaction. The reaction was performed at $37^{\circ} \mathrm{C}$ for $3 \mathrm{~h}$ and terminated by heating at $65^{\circ} \mathrm{C}$ for $20 \mathrm{~min}$. DNA fragments were separated by horizontal electrophoresis through a $0.7 \%$ agarose gel at $25 \mathrm{~V}$ for $16 \mathrm{~h}$ in Tris/Borate/EDTA electrophoresis buffer (Sambrook et al., 1989). DIG-labelled DNA Molecular Weight Marker II (Boehringer Mannheim) was used as a marker. The resultant fragment pattern was visualized under UV light and photographed.

After photography, DNA from the agarose gel was transferred to a positively charged nylon membrane (Boehringer Mannheim) with the VacuGene XL Vacuum Blotting System (Pharmacia) according to the manufacturer's instructions. DNA was bound to the membrane by UV cross-linking. The probe consisted of a PCR-generated 16S rDNA fragment of the type strain of $P$. multocida subsp. multocida (NCTC 10322) amplified with the universal primers $27 \mathrm{f}$ and $1525 \mathrm{r}$ (Lane, 1991). This represents an almost complete copy of the double-stranded 16S rRNA gene sequence of $P$. multocida subsp. multocida NCTC 10322. Before use the probe was labelled with DIG using the DIG DNA Labelling Kit (Boehringer Mannheim). The probe was used at a concentration of 15-20 ng (ml hybridization solution) $)^{-1}$.

Southern hybridization and detection were performed using the Nucleic Acid Detection Kit (Boehringer Mannheim) at a temperature of $68^{\circ} \mathrm{C}$ for both pre-hybridization and hybridization steps and post-hybridization washes. 
Analysis of ribotyping patterns. Fragment patterns were compared visually and distinct patterns were designated as ribotypes. All bands present in the population were identified and each ribotype assigned a band profile with a value of 1 or 0 corresponding to the presence or absence of each band in the population, respectively. A matrix describing the designated band profiles for each ribotype was converted to Ascil file data and imported into the NTSYS computer program. A similarity matrix was constructed according to the Dice co-efficient using the SIMQUAL function of the NTSYS program. A phenogram of genetic similarity was constructed according to the UPGMA clustering strategy using the SAHN clustering and TREE DISPLAY functions of NTSYS.

\section{RESULTS \\ MLEE data}

Only four enzymes (CAT, FUM, GP and HEX) were monomorphic. A total of $71 \mathrm{ET}$ s were identified and the assignment of the isolates to these ETs is shown in Table 1. Australian field isolates were present in 56 ETs and the reference strains were located in 15 ETs. The mean number of alleles per enzyme locus was $3 \cdot 39$. The mean genetic diversity per locus $(b)$ was calculated as 0.302 in relation to the number of ETs or 0.289 when the number of isolates in each ET was included in the calculations. The most variable enzyme, EST, had an $h$ value of $0 \cdot 871$. Estimates of genetic relatedness are presented in the phenogram shown in Fig. 1. The phenogram revealed the existence of three distinct subclusters (A, B and C) separated by a genetic distance of $0 \cdot 36$. MLEE cluster C was represented by a single ET containing one Australian field isolate. A summary of the properties of the isolates within each of these clusters is provided in Table 2.

$I_{\mathrm{A}}$ was calculated as $0.982 \pm 0.011(P<0.05)$ for the 56 ETs containing Australian field isolates. This was significantly different from zero, suggesting that the population was not undergoing significant horizontal gene flow and was clonal.

\section{Ribotype data}

Ribotyping of the $P$. multocida isolates produced well resolved patterns that allowed distinctions to be made between strains (Fig. 2). A total of 21 different patterns or ribotypes, possessing between three and five bands each, were recognized. The allocation of the isolates to the various ribotype patterns is detailed in Table 1.

Estimates of genetic relatedness, based on the ribotyping results, are presented in the phenogram shown in Fig. 3. Nine major clusters (R1-R9) are apparent at a genetic similarity of $0 \cdot 6$. The properties of these nine clusters are summarized in Table 3.

\section{Correlation between serovars, biovars, geographical origin and ET designation}

No isolates of biovar 3 , which was by far the most common biovar $(47 / 81$ field isolates and $7 / 19$ reference stains) were located in MLEE cluster B and only a single isolate of biovar 1 was present in this cluster. Indeed, the biovars appeared to be grouped in specific clusters, with biovars 1,3, 4, 5 and 8 in MLEE cluster A and biovars 2, 6, 7, 9 and 10 in MLEE cluster B.

In terms of the recognized subspecies of $P$. multocida, the MLEE analysis placed both field isolates and the three reference strains belonging to subsp. septica (biovars 7 and 10) and all 13 field isolates belonging to subsp. multocida that produce acid from sorbitol, trehalose and xylose regardless of ODC reaction (biovars 2 and 9) in MLEE cluster B. However, only one of the three reference strains that belonged to biovar 2 were allocated to MLEE cluster B, the other two being in MLEE cluster A.

In contrast, there appeared to be no obvious division of serovars between MLEE clusters A and B. Serovar 3 was the most common serovar overall and was the most common serovar in both MLEE clusters A and B. Only serovar 3 was represented by enough isolates to allow an estimation of genetic diversity $(0 \cdot 286)$.

The 15 ETs containing the 19 reference strains did not include any Australian field isolates. The 16 somatic reference strains were distributed across the diversity of the ET phenogram. The three ETs formed by the type strains for the three subspecies of $P$. multocida (ET R12, ET R13 and ET R15) formed distinct subclusters within MLEE clusters A and B.

\section{ETs and ribotypes}

There was a strong correlation between the MLEE and ribotyping results. All 81 field isolates and 19 reference strains used in the MLEE work were included in the ribotyping study. Within the nine ETs that consisted of more than one isolate $(1,7,11,12,16,20,38,43$ and 50$)$, all members were always allocated to a single ribotype.

At the level of the MLEE and ribotype clusters there was also good agreement. Ribotype cluster R1 contained 17 of the 18 field isolates and all four reference strains assigned to MLEE cluster B. Ribotype cluster R1 also contained only 2 of the 63 field isolates and none of the 15 reference strains assigned to MLEE cluster A. The remaining ribotype clusters (R2-R9) contained 61 of the 63 MLEE cluster A field isolates, the sole remaining MLEE cluster B field isolate and all 15 reference strains assigned to MLEE cluster A. The groupings of strains by ribotype clusters R2-R9 did not closely match the groupings within MLEE cluster A. As an example, isolates in ribotype cluster R3 were located in ETs A7, $\mathrm{A} 8, \mathrm{~A} 11, \mathrm{~A} 24, \mathrm{~A} 25, \mathrm{~A} 26, \mathrm{~A} 28, \mathrm{~A} 29, \mathrm{~A} 30, \mathrm{R} 8, \mathrm{R} 10$ and R11.

\section{Serovars, biovars, geographical origin and ribotypes}

There was no obvious correlation between the serovars and ribotype clusters R1-R9. Within the 15 ribotypes that contained at least two serotyped isolates, all 15 contained at least two serovars, with ribotype 2 containing 11 different serovars. 


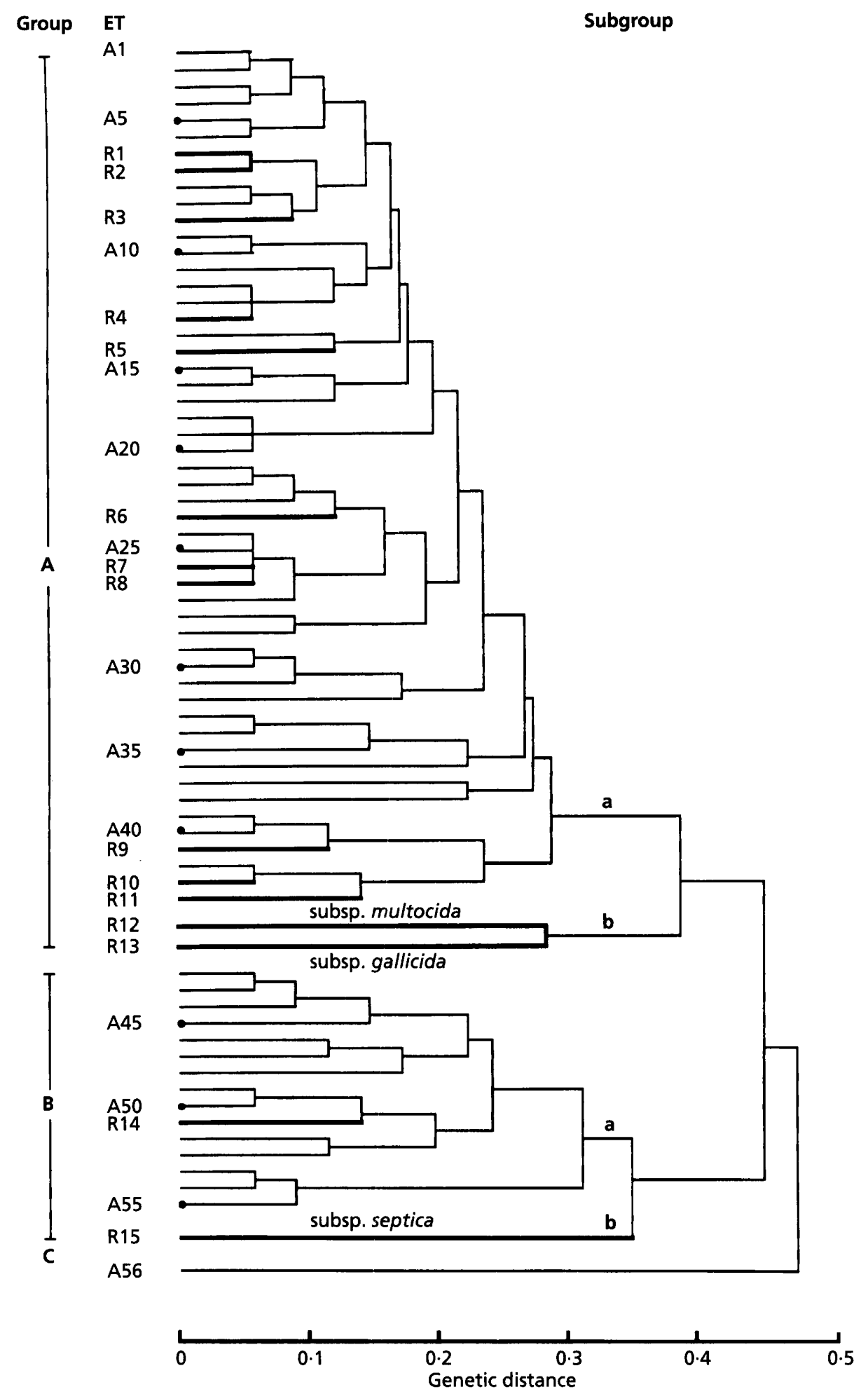

Fig. 1. Phenogram of genetic distance amongst 71 ETS of poultry isolates of $P$. multocida clustered by the UPGMA Strategy. ETs marked A contain Australian field isolates; ETs marked R contain non-Australian reference strains for the 16 somatic serovars and the three subspecies gallicida, multocida and septica.

The 12 multi-isolate ribotypes in clusters $\mathrm{R} 2-\mathrm{R} 9$ contained only a single biovar, with two exceptions. One exception was strain PM17 in ribotype 17 which was biochemical biovar 2 , while the 12 other members of the ribotype were biovar 3 . The other exception was strain PM144 in ribotype 8 which was biovar 2, while the only 
Table 2. Properties of $P$. multocida MLEE clusters

\begin{tabular}{|c|c|c|c|c|}
\hline $\begin{array}{l}\text { MLEE } \\
\text { cluster }\end{array}$ & $\begin{array}{l}\text { No. of } \\
\text { isolates }\end{array}$ & No. of ETs & Biovar/subspecies* & Serovar* \\
\hline \multirow[t]{2}{*}{ A } & 62 & 41 (field isolates) & $\begin{array}{c}1(8), 3(46), 4(2) / \\
\text { multocida }(56)\end{array}$ & $1(2), 3(22), 4(7), 6(1), 10(1), 12(2)$ \\
\hline & & 13 (reference strains) & $\begin{array}{l}5(3) / ? ? ? \text { ? } 3) \\
8(3) / \text { gallicida (3) }\end{array}$ & $\begin{array}{l}\text { Cross-reacting with } 3 \text { and/or } 4 \text { and others (11) } \\
\text { Cross-reacting with serovars other than } 3 \text { or } 4(4) \\
\text { Non-typeable (12) }\end{array}$ \\
\hline \multirow[t]{2}{*}{ B } & 18 & 14 (field isolates) & $\begin{array}{l}1(1), 2(8), 3(1), 9(4) / \\
\text { multocida }(14)\end{array}$ & $1(1), 3(5), 13(1), 14(1)$ \\
\hline & & 2 (reference strains) & $\begin{array}{l}6(2) / \text { ??? (2) } \\
7(1), 10(1) / \text { septica }(2)\end{array}$ & $\begin{array}{l}\text { Cross-reacting with } 3 \text { and/or } 4 \text { and others }(4) \\
\text { Cross-reacting with serovars other than } 3 \text { or } 4 \text { (3) } \\
\text { Non-typeable (3) }\end{array}$ \\
\hline C & 1 & 1 (field isolate) & $2(1) /$ multocida $(1)$ & $1(1)$ \\
\hline
\end{tabular}

* The number of isolates is given in parentheses. ???, cannot be assigned to any of the three recognized subspecies of $P$. multocida.

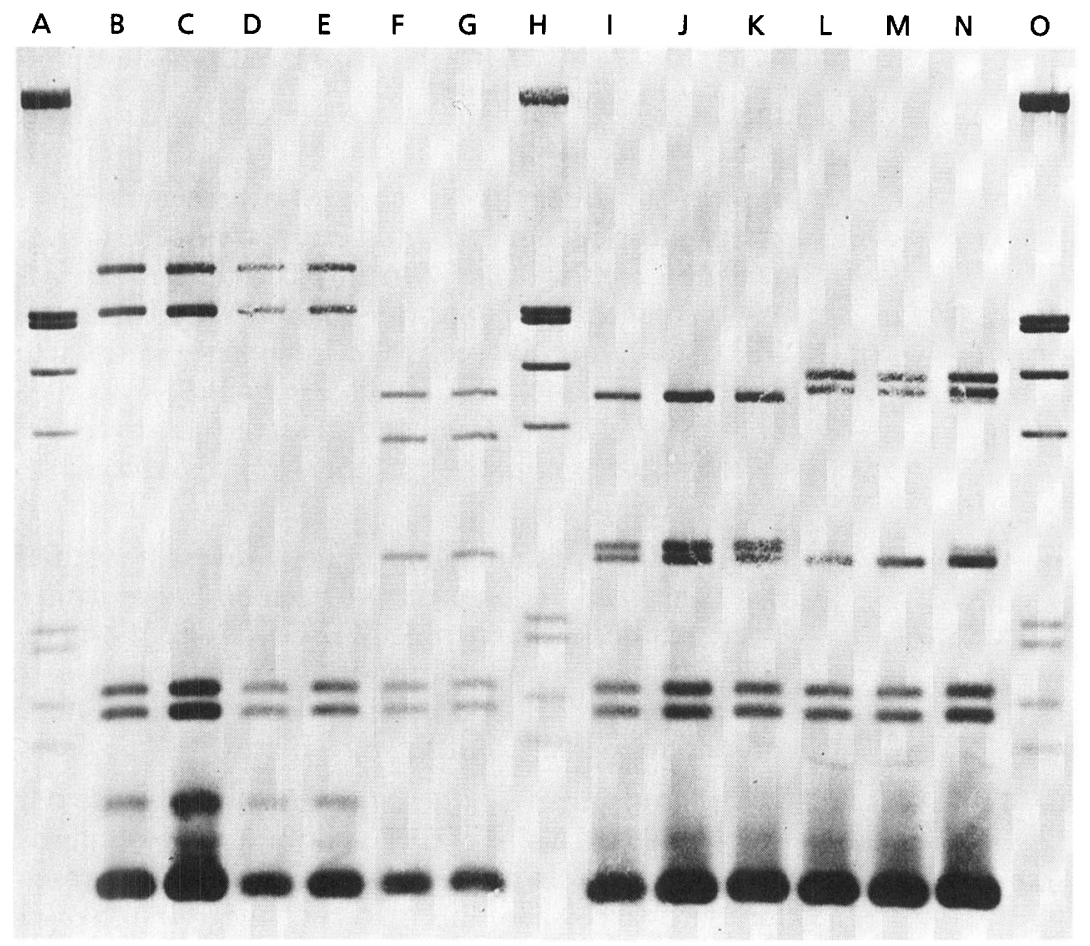

Fig. 2. Examples of ribotyping profiles generated using Hpall. Lanes: $\mathrm{A}, \mathrm{H}$ and $\mathrm{O}$, molecular mass marker; B, PM73; C, PM132; D, PM48; E, PM52; F, PM44; G, PM139; I, PM1; J, PM12; K, PM146; L, PM2; M, PM3; N, PM17.

other member of the ribotype was the reference strain for serovar 2 which was biovar 3 .

In contrast, both ribotypes 4 and 6 within ribotype cluster R1 contained multiple biovars. As an example, ribotype 4 contained six different biochemical biovars $(1,2,6,7,9$ and 10) while ribotype 6 contained three different biovars (2, 5 and 7).

The predominant biovar, biovar 3 , was virtually absent from ribotype cluster R1, with only two of the 68 field isolates of this biovar and none of the seven reference strains occurring in this cluster. Cluster R1 also contained the sole field isolate and all three reference strains of biovar 7 and the sole field isolate of biovar 10. As both of these biovars represent subsp. septica, this means that cluster $\mathrm{R} 1$ contained all the isolates and reference strains of this rare subspecies. Also, cluster R 1 contained all five field isolates of biovar 9, which were ODC-negative variants of subsp. multocida that produce acid from sorbitol, trehalose and xylose. Interestingly, all nine field isolates of subsp. multocida that produced acid from sorbitol, trehalose and xylose but were ODC-positive 


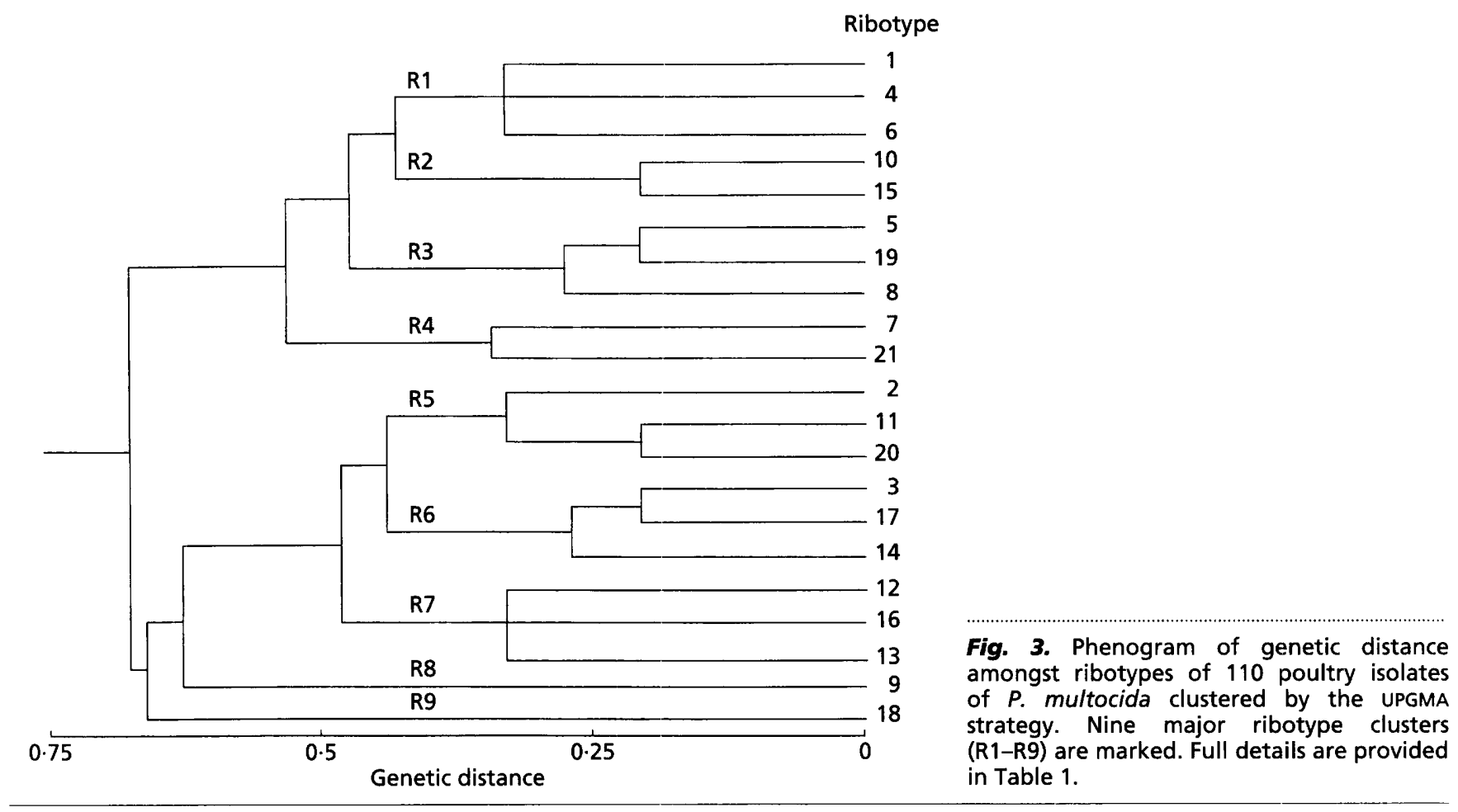

(i.e. biovar 2) were also placed in ribotype cluster R1. However, only one of the three reference strains assigned to biovar 2 was placed in ribotype cluster R1.

The Australian field isolates of biovar 8 (subsp. gallicida) were quite homogeneous with all five strains falling into a single ribotype (ribotype 15 within cluster R2). This was quite different from the reference strain for this subspecies which was the sole member of ribotype 17 within cluster R6.

The 19 non-Australian isolates of $P$. multocida were distributed throughout the 21 ribotypes recognized in this study. Ribotype cluster R9 was the only one to consist solely of non-Australian isolates, while ribotype clusters R2 and R8 were the only ones to consist solely of Australian isolates. Nine of the 19 non-Australian strains formed unique ribotypes that did not contain any Australian isolates: the reference strains for serovars 1, 3 and 14 forming ribotype 16, the reference strain for subsp. gallicida forming ribotype 17, the reference strains for serovars 5 and 16 forming ribotype 18, the reference strains for serovars 12 and 15 forming ribotype 19 and the reference strain for serovar 6 forming ribotype 21.

\section{DISCUSSION}

This study was undertaken to develop an understanding of the population structure of Australian isolates of P. multocida collected from Australian poultry. Selected reference strains from outside Australia were used to validate the results of the study.

Overall, the genetic diversity of the isolates as detected by MLEE $(0.302)$ was consistent with the results for other species of animal-pathogenic bacteria. For ex- ample, the diversity is somewhat lower than that reported for such non-avian veterinary bacterial pathogens as Streptococcus suis (0.512) (Hampson et al., 1993b) and Escherichia coli (0.47) (Woodward et al., 1993), similar to that seen in the related porcine bacterial pathogen Actinobacillus pleuropneumoniae (0.312) (Hampson et al., 1993a) and greater than that seen in another porcine pathogen, Serpulina byodysenteriae (0.260) (Lee et al., 1993).

To date, the only published genetic diversity studies on avian bacterial pathogens have been on Escherichia coli. These studies (Whittam \& Wilson, 1988; White et al., 1993a, b) have reported broadly similar genetic diversity figures $(0.30,0.355$ and 0.37$)$ to those obtained here for Australian avian $P$. multocida isolates.

Of the multiplicity of serovars included in the MLEE study, only serovar 3 was present in sufficient number to warrant a meaningful analysis. The diversity present in this serovar (0.286) approached that for the whole collection, demonstrating that serotyping is not useful in establishing relationships between isolates of avian P. multocida.

Of the two main clusters recognized by MLEE, biovar 3 field isolates and reference strains were virtually absent from cluster B. As biovar 3 is by far the most common biochemical type of $P$. multocida present in Australian poultry (Fegan et al., 1995), this absence of biovar 3 from cluster B is noteworthy. The association of biovar 3 with cluster A suggests that there is some underlying genetic background responsible for this grouping.

Considerable diversity was recognized by ribotyping with a total of 21 ribotype patterns being recognized. The level of subdivision achieved with ribotyping was 
Table 3. Properties of the $P$. multocida isolates in the ribotype clusters

\begin{tabular}{|c|c|c|c|c|c|c|c|}
\hline $\begin{array}{l}\text { Ribotype } \\
\text { cluster }\end{array}$ & $\begin{array}{c}\text { No. of } \\
\text { isolates }\end{array}$ & Serovar $†$ & Ribotype & ET & ET cluster $\dagger$ & Biovart & Subspeciest \\
\hline $\mathrm{R} 1$ & $27(4)$ & $\begin{array}{l}1(2), 3(5), 4(1), 7(2), 8(1), 9(1), 13(1), 14(1) \\
\text { Cross-reacting with } 3 \text { and/or } 4 \text { and others }(4) \\
\text { Cross-reacting with serovars other than } 3 \text { or } 4 \\
(4) \\
\text { Non-typeable (4) }\end{array}$ & $1,4,6$ & $\begin{array}{l}\text { A } 35-36 \\
\text { A42-44, } \\
\text { A46-55 } \\
\text { R } 14-15\end{array}$ & $\begin{array}{l}\text { A }(2) \\
\text { B }(21)\end{array}$ & $\begin{array}{l}1(1) \\
2(10) \\
3(2) \\
9(5) \\
5(2) \\
6(2) \\
7(4) \\
10(1)\end{array}$ & $\begin{array}{l}\text { multocida } \\
(18) \\
\text { septica }(5) \\
\text { ??? (4) } \neq\end{array}$ \\
\hline $\mathrm{R} 2$ & $11(0)$ & $\begin{array}{l}1(2), 3(3) \\
\text { Cross-reacting with serovars other than } 3 \text { or } 4 \\
(2)\end{array}$ & 10,15 & $\begin{array}{l}\text { A21-23, } \\
\text { A39-40, A56 }\end{array}$ & $\begin{array}{l}A(5) \\
C(1)\end{array}$ & $\begin{array}{l}3(6) \\
8(5)\end{array}$ & $\begin{array}{l}\text { multocida }(6) \\
\text { gallicida }(5)\end{array}$ \\
\hline R3 & $28(4)$ & $\begin{array}{l}2(1), 3(15), 7(1), 12(1), 15(1) \\
\text { Cross-reacting with } 3 \text { and/or } 4 \text { and others (4) } \\
\text { Non-typeable (1) }\end{array}$ & $5,8,19$ & $\begin{array}{l}\text { A7-8, A11, } \\
\text { A24-26, A28, } \\
\text { A29-32, A41 } \\
\text { R2, R8, } \\
\text { R10, R11 }\end{array}$ & A $(20)$ & $\begin{array}{l}2(2) \\
3(26)\end{array}$ & $\begin{array}{l}\text { multocida } \\
(28)\end{array}$ \\
\hline R4 & $17(2)$ & $\begin{array}{l}3(2), 4(3), 6(2) \\
\text { Cross-reacting with } 3 \text { and/or } 4 \text { and others (1) } \\
\text { Cross-reacting with serovars other than } 3 \text { or } 4 \\
(2) \\
\text { Non-typeable }(5)\end{array}$ & 7,21 & $\begin{array}{l}\mathrm{A} 3, \mathrm{~A} 38, \mathrm{~A} 45 \\
\mathrm{R} 4, \mathrm{R} 9\end{array}$ & $\begin{array}{l}\mathrm{A}(15) \\
\mathrm{B}(1)\end{array}$ & $\begin{array}{l}1(3) \\
2(1) \\
3(13)\end{array}$ & $\begin{array}{l}\text { multocida } \\
(17)\end{array}$ \\
\hline R5 & $28(2)$ & $\begin{array}{l}3(4), 4(3), 10(1), 11(1), 12(2) \\
\text { Cross-reacting with } 3 \text { and/or } 4 \text { and others (4) } \\
\text { Non-typeable (4) }\end{array}$ & $2,11,20$ & $\begin{array}{l}\text { A1-2, A5, } \\
\text { A12-13, } \\
\text { A18-20, } \\
\text { A33-34 } \\
\text { R3, R10 }\end{array}$ & A (17) & $\begin{array}{l}1(2) \\
3(26)\end{array}$ & $\begin{array}{l}\text { multocida } \\
(28)\end{array}$ \\
\hline R6 & $4(1)$ & $\begin{array}{l}\text { Cross-reacting with } 3 \text { and/or } 4 \text { and others }(1) \\
\text { Cross-reacting with serovars other than } 3 \text { or } 4 \\
\text { (1) } \\
\text { Non-typeable (1) }\end{array}$ & $3,14,17$ & $\begin{array}{l}\text { A9-10, A27 } \\
\text { R13 }\end{array}$ & A (4) & $\begin{array}{r}1(3) \\
11(1)\end{array}$ & $\begin{array}{l}\text { multocida }(3) \\
\text { gallicida }(1)\end{array}$ \\
\hline R7 & $9(4)$ & $\begin{array}{l}1(1), 3(2), 13(1), 14(1) \\
\text { Cross-reacting with } 3 \text { and/or } 4 \text { and others (1) } \\
\text { Non-typeable (2) }\end{array}$ & $12,13,16$ & $\begin{array}{l}\text { A4, A6, A } 14 \\
\text { A17, A37 } \\
\text { R5-6, R12 }\end{array}$ & $A(9)$ & $\begin{array}{r}1(5) \\
2(1) \\
4(2) \\
11(1)\end{array}$ & $\begin{array}{l}\text { multocida }(8) \\
\text { gallicida }(1)\end{array}$ \\
\hline R8 & $3(0)$ & $\begin{array}{l}3(1), 4(1) \\
\text { Non-typeable }(1)\end{array}$ & 9 & A15-16 & $A(3)$ & $5(3)$ & $? ? ?(3) \neq$ \\
\hline R9 & $2(2)$ & $5(1), 16(1)$ & 18 & $\mathrm{R} 1, \mathrm{R} 7$ & $A(2)$ & $3(2)$ & multocida (2) \\
\hline
\end{tabular}

* The number of non-Australian reference strains is given in parentheses.

†The number of strains in the serovar, MLEE cluster, biovar or subspecies is given in parentheses.

$\ddagger$ ???, cannot be assigned to any of the three recognized subspecies of $P$. multocida.

less than that obtained using MLEE on the subset of strains examined by both techniques (56 ETs recognized in field isolates and $15 \mathrm{ETs}$ in the reference strains). This failure of ribotyping to yield as much subtyping information as MLEE is unusual as previous studies on other bacterial species have reported that ribotyping is capable of producing a finer typing of strains than MLEE (Woods et al., 1992; Ng \& Dillon, 1993). Overall, the ribotyping results support the finding of the MLEE study that a diverse range of $P$. multocida strains are 
associated with fowl cholera in Australian poultry. Although diverse, this population was also clonal with diverse ETs evolving during the course of descent rather than by convergence through extensive lateral gene flow (Maynard Smith et al., 1993; Musser, 1996). Thus the $I_{A}$ was significantly different from zero, suggesting that recombination between the Australian field isolates was not common enough to generate a random assortment of alleles.

In general, the results of the cluster analysis performed on the ribotype patterns supported the clusters recognized in the MLEE study. In particular, ribotype cluster $\mathrm{R} 1$ was a very close match to MLEE cluster $\mathrm{B}$. Hence, by two different methods, these groups of $P$. multocida isolates have been shown to be closely related to each other and distinguishable from other isolates. There are several unusual aspects to the organisms that make up the complex formed by ribotype cluster R1/MLEE cluster B. First, there is the virtual absence of biovar 3 isolates from the group, despite this biovar being by far the most common biovar amongst Australian isolates of P. multocida from poultry (Fegan et al., 1995). Also, biovar 3 was the most common biovar amongst the nonAustralian reference strains of $P$. multocida $(7 / 19)$, yet none of four non-Australian isolates of $P$. multocida assigned to ribotype cluster R1 were biovar 3. Second, both field isolates and all three reference strains of subsp. septica (biovars 7 and 10) were placed in this complex. These five isolates were quite diverse in their origin, consisting of two serovar reference strains (ATS7 and 8), the type strain for subsp. septica, an Australian isolate that has the typical properties of subsp. septica and another Australian isolate that is unusual in that it is a maltose-positive variant of subsp. septica. A third unusual aspect of this complex of organisms is the presence of all five ODC-negative variants of subsp. multocida (biovar 9). Biovar 9 only differs from biovar 2 in being ODC-negative, both biovars being capable of producing acid from sorbitol, trehalose and xylose. Ribotyping and MLEE placed all field isolates of both of these biovars ( 2 and 9) together in the single complex.

Overall, the organisms of ribotype cluster R1/MLEE cluster B make up a biochemically and serologically diverse group that are notable for the unusual biochemical patterns and the absence of the predominant biovar 3. Despite this biochemical and serological diversity, both MLEE and ribotyping have clustered these organisms together, suggesting that they have a common genetic background.

The 19 reference strains were distributed across the full diversity of the Australian isolates of $P$. multocida. Furthermore, as 10 of the 19 strains were allocated to ribotypes that also contained Australian isolates, Australian isolates of $P$. multocida are unlikely to be markedly different from those found in other countries.

In summary, this study has demonstrated for the first time that avian $P$. multocida isolates form a clonal population. Within this structure, both MLEE and ribotyping have identified a subgroup of $P$. multocida that have unusual biochemical properties. This subgrouping cuts across the currently recognized subspecies within $P$. multocida (gallicida, multocida and septica). We have also shown for the first time that somatic serotyping is not a useful means of establishing relationships between isolates of $P$. multocida.

\section{ACKNOWLEDGEMENTS}

We gratefully acknowledge the financial support of the Australian Chicken Meat Research and Development Corporation through the Australian Rural Industries Research and Development Corporation. The serotyping of the $P$. multocida isolates was performed at the Victorian Institute of Animal Sciences, Attwood, Victoria, Australia.

\section{REFERENCES}

Blackall, P. J., Pahoff, J. L., Marks, D., Fegan, N. \& Morrow, C. J. (1995). Characterisation of Pasteurella multocida isolates from fowl cholera outbreaks on seven turkey farms. Aust Vet J 72, 135-138.

Carpenter, T. E., Snipes, K. P., Kasten, R. W., Hird, D. W. \& Hirsh, D. C. (1991). Molecular epidemiology of Pasteurella multocida in turkeys. Am J Vet Res 52, 1345-1349.

Christiansen, K. H., Carpenter, T. E., Snipes, K. P. \& Hird, D. W. (1992a). Transmission of Pasteurella multocida on Californian turkey premises in 1988-89. Avian Dis 36, 262-271.

Christiansen, K. H., Carpenter, T. E., Snipes, K. P., Hird, D. W. \& Ghazikhanian, Y. (1992b). Restriction endonuclease analysis of Pasteurella multocida isolates from three California turkey premises. Avian Dis 36, 272-281.

Fegan, N., Blackall, P. J. \& Pahoff, J. L. (1995). Phenotypic characterisation of Pasteurella multocida isolates from Australian poultry. Vet Microbiol 47, 281-286.

Feizabadi, M. M., Robertson, I. D., Cousins, D. V., Dawson, D., Chew, W., Gilbert, G. L. \& Hampson, D. J. (1996). Genetic characterization of Mycobacterium avium isolates recovered from humans and animals in Australia. Epidemiol Infect 116, $41-49$.

Hampson, D. J., Blackall, P. J., Woodward, J. M. \& Lymbery, A. J. (1993a). Genetic analysis of Actinobacillus pleuropneumoniae and comparison with Haemophilus Taxon 'minor group' and Taxon C. Zentralbl Bakteriol 279, 83-91.

Hampson, D. J., Trott, D. J., Clarke, I. L., Mwaniki, C. G. \& Robertson, I. D. (1993b). Population structure of Australian isolates of Streptococcus suis. J Clin Microbiol 31, 2895-2900.

Heddleston, K. L., Gallagher, J. E. \& Rebers, P. A. (1972). Fowl cholera: gel diffusion precipitin test for serotyping Pasteurella multocida from avian species. Avian Dis 16, 925-936.

Hirsh, D. C., Jessup, D. A., Snipes, K. P., Carpenter, T. E., Hird, D. W. \& McCapes, R. C. (1990). Characteristics of Pasteurella multocida isolated from waterfowl and associated avian species in California. J Wildl Dis 26, 204-209.

Kim, C. J. \& Nagaraja, K. V. (1990). DNA fingerprinting for differentiation of field isolates from reference vaccine strains of Pasteurella multocida in turkeys. Am J Vet Res 51, 207-210.

Lane, D. J. (1991). 16S/23S rRNA sequencing. In Nucleic Acid Techniques in Bacterial Systematics, pp. 115-175. Edited by E. Stackebrandt \& M. Goodfellow. Chichester: Wiley.

Lee, J. I., Hampson, D. J., Combs, B. G. \& Lymbery, A. J. (1993). Genetic relationships between isolates of Serpulina (Treponema) 
byodysenteriae, and comparison of methods for their subspecific differentiation. Vet Microbiol 34, 35-46.

Maynard Smith, J., Smith, N. H., O'Rourke, M. \& Spratt, B. G. (1993). How clonal are bacteria? Proc Natl Acad Sci USA 90, 4384.4388

Musser, J. M. (1996). Molecular population genetic analysis of emerged bacterial pathogens: selected insights. Emerg Infect Dis 2, 1-17.

Mutters, R., Ihm, P., Pohl, S., Frederiksen, W. \& Mannheim, W. (1985). Reclassification of the genus Pasteurella Trevisan 1887 on the basis of deoxyribonucleic acid homology, with proposals for the new species Pasteurella dagmatis, Pasteurella canis, Pasteurella stomatis, Pasteurella anatis, and Pasteurella langaa. Int J Syst Bacteriol 35, 309-322.

Nei, M. (1978). Estimation of average heterozygosity and genetic distance from a small number of individuals. Gene 89, 583-590.

Ng, L. K. \& Dillon, J. R. (1993). Typing by serovar, antibiogram, plasmid content, riboprobing, and isoenzyme typing to determine whether Neisseria gonorrhoeae isolates requiring proline, citrulline, and uracil for growth are clonal. J Clin Microbiol 31, 1555-1561.

O'Farrell, P. H., Kutter, E. \& Nakanishi, M. (1980). A restriction map of the bacteriophage T4 genome. Mol Gen Genet 179, $421-435$.

Quentin, R., Huet, H., Wang, F.-S., Geslin, P., Goudeau, A. \& Selander, R. K. (1995). Characterization of Streptococcus agalactiae strains by multilocus enzyme genotype and serotype: identification of multiple virulent clone families that cause invasive neonatal disease. J Clin Microbiol 33, 2576-2581.

Rhoades, K. R. \& Rimler, R. B. (1987). Capsular groups of Pasteurella multocida isolated from avian hosts. Avian Dis 31, 895-898.

Rimler, R. B. \& Glisson, J. R. (1997). Fowl cholera. In Diseases of Poultry, pp. 143-159. Edited by B. W. Calnek, H. J. Barnes, C. W. Beard, L. R. McDougald \& Y. M. Saif. Ames: Iowa State University Press.

Sambrook, J., Fritsch, E. F. \& Maniatis, T. (1989). Molecular Cloning: a Laboratory Manual, 2nd edn. Cold Spring Harbor, NY: Cold Spring Harbor Laboratory.

Selander, R. K., Caugant, D. A., Ochman, H., Musser, J. M., Gilmour, M. N. \& Whittam, T. S. (1986). Methods of multilocus enzyme electrophoresis for bacterial population genetics and systematics. Appl Environ Microbiol 51, 873-884.
Sneath, P. H. A. \& Sokal, R. R. (1973). Numerical Taxonomy. San Francisco: W. H. Freeman \& Co.

Snipes, K. P., Hirsh, D. C., Kasten, R. W., Carpenter, T. E., Hird, D. W. \& McCapes, R. H. (1990). Differentiation of field isolates of Pasteurella multocida serotype 3,4 from live vaccine strain by genotypic characterization. Avian Dis 34, 419-424.

Tomayko, J. F. \& Murray, B. E. (1995). Analysis of Enterococcus faecalis isolates from intercontinental sources by multilocus enzyme electrophoresis and pulsed-field gel electrophoresis. J Clin Microbiol 33, 2903-2907.

Weis, N. \& Lind, I. (1996). Usefulness of the DNA-fingerprinting pattern and the multilocus enzyme electrophoresis profile in the assessment of outbreaks of meningococcal disease. Epidemiol Infect 116, 103-114.

White, D. G., Dho-Moulin, M., Wilson, R. A. \& Whittam, T. S. (1993a). Clonal relationships and variation in virulence among Escherichia coli strains of avian origin. Microb Pathog 14, 399-409.

White, D. G., Wilson, R. A., Emery, D. A., Nagaraja, K. V. \& Whittam, T. S. (1993b). Clonal diversity among strains of Escherichia coli incriminated in turkey colisepticemia. Vet Microbiol 34, 19-34.

Whittam, T. S. \& Wilson, R. A. (1988). Genetic relationships among pathogenic strains of avian Escherichia coli. Infect Immun 56, 2458-2466.

Wilson, M. A., Morgan, M. J. \& Barger, G. E. (1993). Comparison of DNA fingerprinting and serotyping for identification of avian Pasteurella multocida isolates. J Clin Microbiol 31, 255-259.

Wilson, M. A., Duncan, R. M., Nordholm, G. E. \& Berlowkski, B. M. (1995). Pasteurella multocida isolated from wild birds of North America : a serotype and DNA fingerprint study of isolates from 1978 to 1993. Avian Dis 39, 587-593.

Woods, T. C., Helsel, L. O., Swaminathan, B., Bibb, W. F., Pinner, R. W., Gellin, B. G., Collin, S. F., Waterman, S. H., Reeves, M. W., Brenner, D. J. \& Broome, C. V. (1992). Characterization of Neisseria meningitidis serogroup $C$ by multilocus enzyme electrophoresis and ribosomal DNA restriction endonuclease profiles (ribotyping). J Clin Microbiol 30, 132-137.

Woodward, J. M., Connaughton, I. D., Fahy, V. A., Lymbery, A. J. \& Hampson, D. J. (1993). Clonal analysis of Escherichia coli of serogroups O9, O20, and $\mathrm{O} 101$ isolated from Australian pigs with neonatal diarrhea. J Clin Microbiol 31, 1185-1188.

Received 22 September 1997; accepted 30 October 1997. 